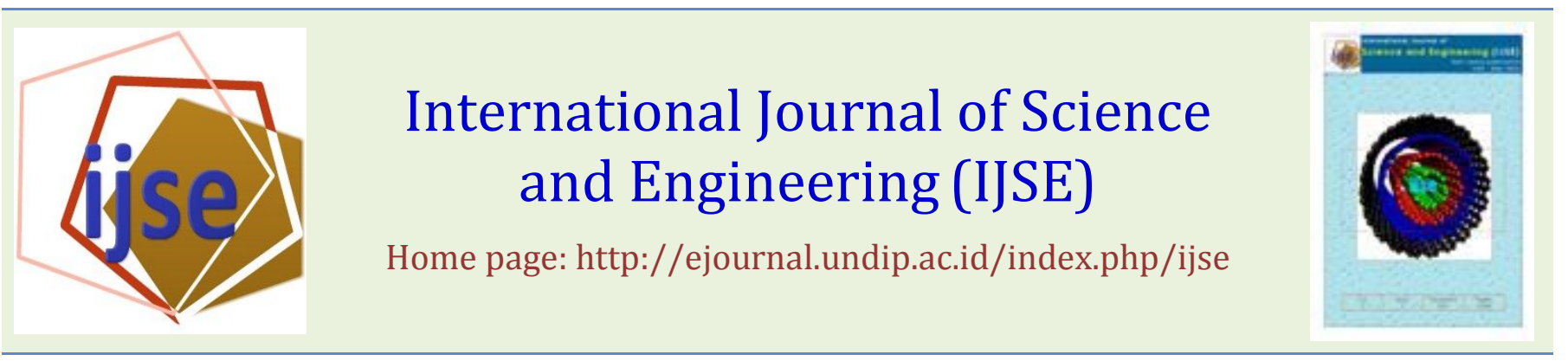

\title{
The Effect of Fe-Enrich Phase on The Pitting Corrosion Resistance of Al Alloy In Various Neutral Sodium Chloride Solutions
}

\author{
Gadang Priyotomo ${ }^{1}$, I Nyoman Gede Putrayasa Astawa \\ Research Center for Metallurgy and Material, Indonesian Institute of Sciences \\ Kawasan PUSPIPTEK Gd.474 Setu, Tangerang Selatan, Banten, Indonesia \\ 1gadangp@gmail.com
}

\begin{abstract}
The pitting corrosion of 5052 alloy was investigated as function of chloride concentrations by using an electrochemical method, scanning electron microscope and energy dispersive X-Ray spectroscopy in neutral sodium chloride solutions at $293 \mathrm{~K}$. The pitting corrosion of pure $\mathrm{Al}$ was also investigated under the same experimental condition for the comparison. The pitting potential obtained for 5052 alloy and pure $\mathrm{Al}$ decreased with increasing chloride concentration. The pitting potential of pure Al is higher than that of 5052 alloy where pitting resistance of pure $\mathrm{Al}$ is better than that 5052 alloy. The linear equation implies that certain pitting potential becomes a relevant parameter for predicting certain chloride ion concentration. The synergic role of chloride ion and a localized galvanic corrosion between aluminium metal and iron-containing constituent contribute the process of pitting for 5052 alloy.

Keywords - Pitting Corrosion, Pitting Potential, Galvanic Coupling, Chloride Ion
\end{abstract}

Submission: August 27, $2014 \quad$ Corrected : September 20, 2014

Accepted:September 30, 2014

Doi: $10.12777 /$ ijse.7.2.143-149

[How to cite this article: Priyotomo, G. and ${ }^{1}$, Astawa, I N. G.P. . (2014). The Effect of Fe-Enrich Phase on The Pitting Corrosion Resistance of Al Alloy In Various Neutral Sodium Chloride Solutions , International Journal of Science and Engineering, 7(2),143-149. Doi: 10.12777/ijse.7.1.143149]

\section{INTRODUCTION}

The properties of aluminium (Al) that make this alloy the most economical and attractive for a wide variety of uses in industries and human appliances are good appearance, light weight, fabricability, physical properties, mechanical properties, and corrosion resistance(Elwin et al.,1990, Guozhe et al.,2009). On the other hand, an improvement in the mechanical properties of aluminium alloy was attempted by macro-alloying by magnesium (Mg), ferrous (Fe), silicon (Si) and Chromium (Cr) which enhanced high-strength. The other improvements of these additional elements added $\mathrm{Al}$ alloy are good welding characteristic and good resistance to corrosion in marine atmospheres (Elwin et al.,1990). The second phases occur with the presence of additional elements in Al alloy.

Although aluminium with and without the addition of $\mathrm{Mg}$ generally is corrosion resistant between $\mathrm{pH} 4$ and 9 due to the presence of a protective oxide layer (Kciuk et al.,2010), pitting corrosion is known to take place. It is induced by chloride-containing environments and enhanced by the localized acidification in such environments caused by hydrolysis of water within the pits, according to the reaction (Lockwood, et al.,1985):

$$
\mathrm{M}^{+}+\mathrm{Cl}^{-}+\mathrm{H}_{2} \mathrm{O} \rightarrow \mathrm{MOH}+\mathrm{HCl}
$$

On the basis of the present investigation, Minhua shao and co-workers had found that pitting corrosion often initiates on or around the second phases particles in Al 2024-T3 alloy (Shao eta al.,2002). On the other preceding investigations, Priyotomo and co-workers had also found that this corrosion took place on the second phases of $\left(\mathrm{L} 1_{2}+\mathrm{Ni}_{\mathrm{ss}}\right)$ region comparing to a matrix of $\mathrm{L} 1_{2}$ single phase in nickel alloy with the addition of $\mathrm{Al}$ (Priyotomo et al., 2011, Priyotomo et al., 2012). In addition, Priyotomo and co-workers also found that the detrimental effect of second phase decreases the corrosion resistance of nickel alloy with the addition of $\mathrm{Cr}$ in acid solution containing chloride ion (Priyotomo et al., 2012)

Furthermore, with regard to $\mathrm{Al}$ alloy with the addition of $\mathrm{Mg}$ and the other minor elements such as Fe, $\mathrm{Cr}$, and $\mathrm{Si} \mathrm{(Al} \mathrm{5052),} \mathrm{there} \mathrm{is} \mathrm{little} \mathrm{study} \mathrm{on} \mathrm{their} \mathrm{corrosion}$ behaviour in aqueous solutions containing chloride ion at 
ambient temperature. Therefore, the objective of this work is to elucidate the corrosion behavior of $\mathrm{Al} 5052$ compared to pure $\mathrm{Al}$ in aqueous solutions containing chloride ion.

\section{EXPERIMENTAL}

\section{A. The specimens and test solutions}

In this present work, as-received specimens consist of 5052 alloy. The specimen was conducted a solution annealing heat treatment at $343^{\circ} \mathrm{C}$ for 1 hour under an air atmosphere and then cooled in a muffle furnace. After that, the specimen was cut into $3 \mathrm{~mm} \times 10 \mathrm{~mm} \times 10 \mathrm{~mm}$. Then it was polished to 1200 grit silica carbide paper, degreased by acetone in an ultrasonic cleaner and washed with distilled water. The test solutions used were sodium chloride solutions with various chloride ion concentrations $(0.001 \mathrm{M}-1 \mathrm{M})$ prepared from distilled water and guaranteed grade reagent. Pure $\mathrm{Al}$ alloy was as the reference for the experiments. The chemical compositions of those prepared materials are given in Table 1.

Table 1. Composition of the materials investigated

\begin{tabular}{|c|c|c|}
\hline \multirow{2}{*}{ Elements } & Al-5052 & $\mathrm{Al} 99,99$ \\
\cline { 2 - 3 } & \multicolumn{2}{|c|}{ At. \% } \\
\hline $\mathrm{Mg}$ & 2.66 & 0.006 \\
$\mathrm{Si}$ & 0.13 & 0.006 \\
$\mathrm{Fe}$ & 0.27 & 0.006 \\
$\mathrm{Cu}$ & 0.0007 & 0.006 \\
$\mathrm{Mn}$ & 0.006 & 0.002 \\
$\mathrm{Zn}$ & 0.012 & 0.006 \\
$\mathrm{Cr}$ & 0.23 & 0.000 \\
$\mathrm{Al}$ & 96.63 & 99.968 \\
\hline
\end{tabular}

Micro structural observation was conducted by applying a scanning electron microscope (SEM; JEOL, JED2300 operating at $20 \mathrm{kV}$ ). The structure of the specimen was also determined by X-ray diffraction with $\mathrm{Cu} \mathrm{Ka}$ radiation using an X-ray diffractometer.

\section{B. Electrochemical test}

Electrochemical experiments were conducted in a round bottom cell of $1000 \mathrm{ml}$ capacity using a potentiostat (Reference 600,Gamry Instrument), interfaced to a personal computer. The potentials were measured using a saturated calomel electrode (SCE). All the potentials referred in this work are with respect to SCE. The surface of the working electrode was covered with resin to expose a working area of $1 \mathrm{~cm}^{2}$. A platinum wire served as the counter electrode. Prior to anodic polarization test, the open circuit potential (OCP) was monitored and experiments were begun after stabilization of OCP. Those experiments were conducted at a scan rate of $0.167 \mathrm{mV} / \mathrm{s}$. After the experiments, the morphology and distributed elements on the specimen surface was investigated by using SEM and energy dispersive X-ray spectrometer.

\section{RESULTS AND DISCUSSION}

A. Microstructure of 5052 aluminium alloy before immersion test

The microstructure of 5052 aluminium alloy before electrochemical test is shown in Fig. 1. This alloy consists of two structure phases; $\mathrm{FeAl}_{3}$ (white area) and $\mathrm{Mg}_{2} \mathrm{Si}$ (dark area). This microstructure obtained was the same as that observed by Lockwood et.al (Lockwood et al). Fig. 2 shows the surface distribution of elements for 5052 aluminium alloy before the electrochemical test. The major element Al was present uniformly. Furthermore, on 5052 alloy, the element of Fe was enriched Feenriched phase, while $\mathrm{Mg}$ and Si was distributed densely in the $\mathrm{Mg} \& \mathrm{Si}$ - enriched phase.

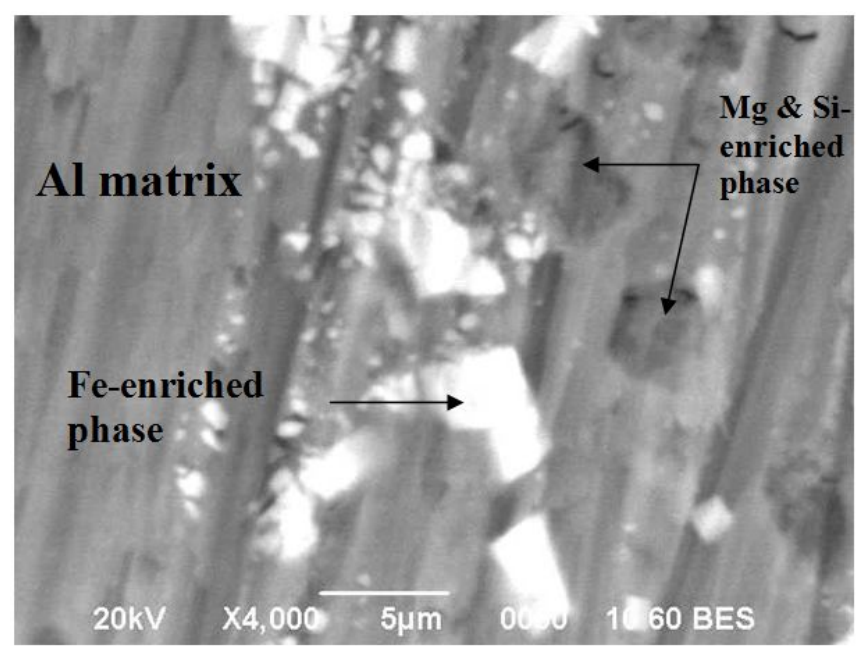

Fig. 1. Microstructures of 5052 alloy before the electrochemical test

\section{B. Determination of pitting potential $\left(E_{\text {pit }}\right)$}

Fig. 3 shows anodic polarization curves for pure $\mathrm{Al}$ in neutral sodium chloride solutions with various chloride concentrations at $293 \mathrm{~K}$. The anodic current densities of these alloys were negligibly low up to a certain applied potential, which corresponded to a passive current density. The anodic current density began to increase above a certain applied potential and increased rapidly with increasing applied potential. As shown in the inset figure in Fig. 3, $E_{\text {pit }}$ was measured through the extrapolation of the increased anodic current density to the passive current density. Fig 4 also shows anodic polarization curves for 5052 alloy in neutral sodium chloride solutions with various chloride concentrations at 293 K. The determination of $E_{\text {pit }}$ for Fig. 4 was the same method with that for Fig.3. 

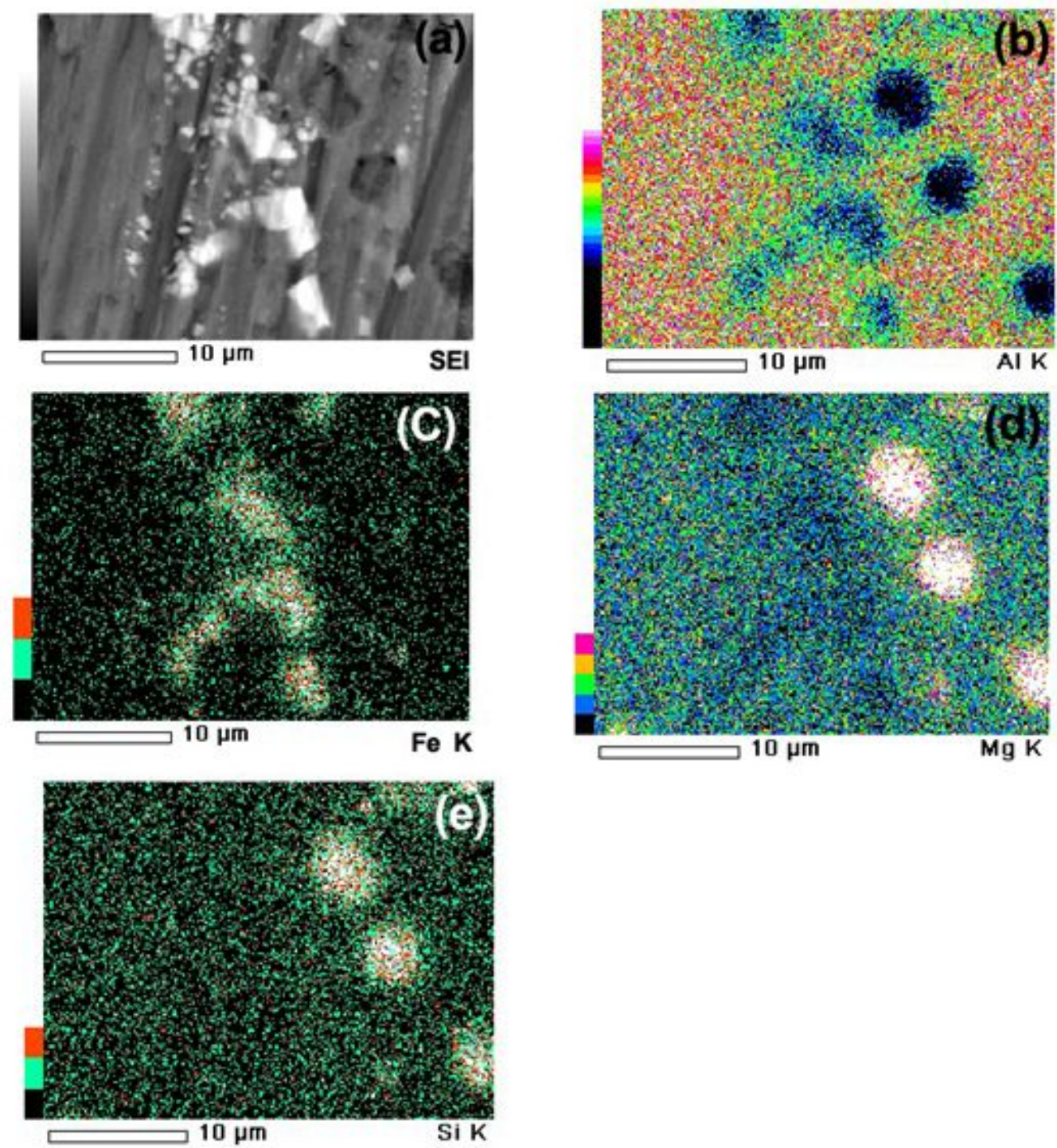

Fig. 2. Element distribution of 5052 alloy before the electrochemical test, (a) SEM; (b) Al; (c) Fe; (d) Mg; and (e) Si.

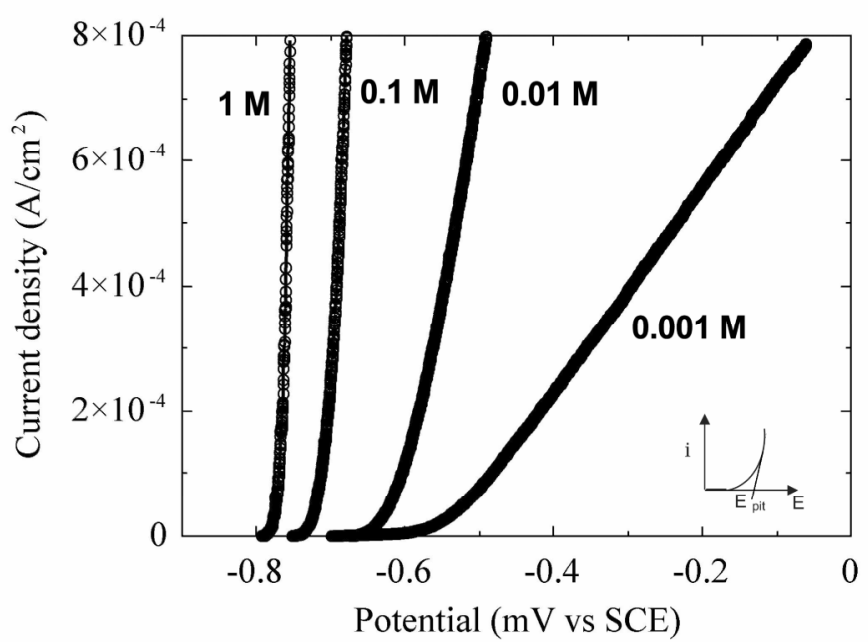

Fig.3. Anodic polarization curves for pure Al with various chloride concentrations at $293 \mathrm{~K}$. 


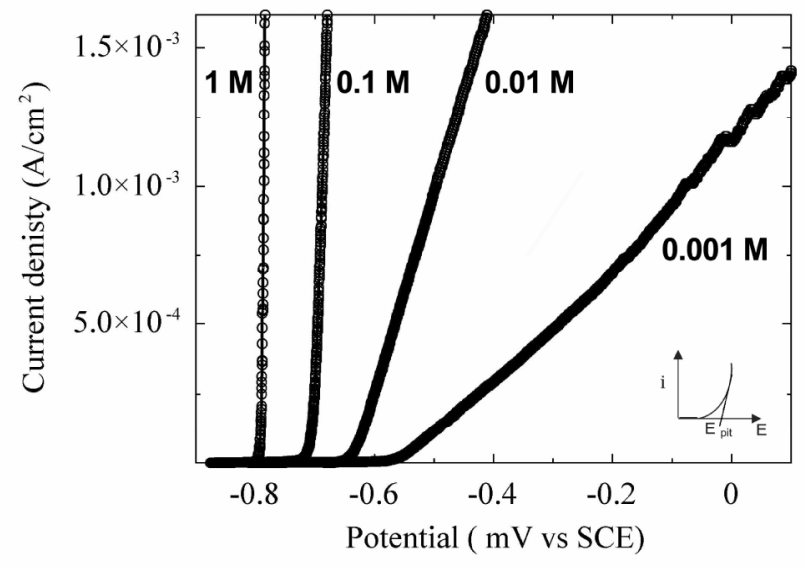

Fig.4. anodic polarization curves for 5052 alloy with various chloride concentrations at $293 \mathrm{~K}$.
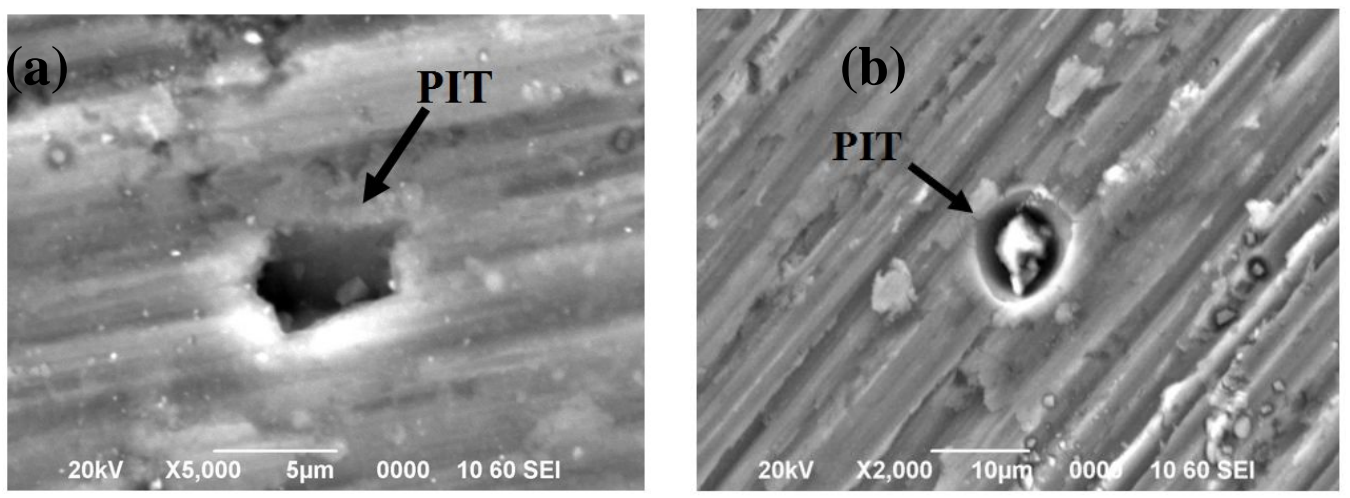

Fig. 5. Surface appearances of (a). pure Al and (b) 5052 alloy after electrochemical test at $293 \mathrm{~K}$ in $0.1 \mathrm{M} \mathrm{NaCl} \mathrm{solution.}$

Fig. 5(a) shows a figure of a pit appearance for pure $\mathrm{Al}$ after carrying out electrochemical test in $0.1 \mathrm{M}$ neutral sodium chloride solution at $293 \mathrm{~K}$ by applying SEM. This proof shows that the rapid rise in anodic current density is induced by the formation of the pit with the size of 5 m. On the other hand, Fig.5(b) shows a figure of pit appearance for 5052 alloy after conducting that test in $0.1 \mathrm{M}$ neutral sodium chloride solution at $293 \mathrm{~K}$. In this figure, the size of pit is about $8 \mathrm{~m}$.

\section{Effect of chloride concentration}

Fig. 6 shows chloride concentration dependence of pitting potential for 5052 alloy and pure $\mathrm{Al}$ in various neutral sodium chloride solutions at temperature of 293 $\mathrm{K}$. It was found clearly that pitting potentials of both alloys increased linearly with decreasing chloride concentration up to a certain chloride concentration, below which no pitting corrosion took place as well as those of several nickel-based intermetallic compounds (Priyotomo et al.,2013 ; Priyotomo et al.,2014a ; Priyotomo et al.,2014b ; wagle et al.,2011). On the basis of the results, there are no a critical chloride concentration $\left(\mathrm{Cl}^{-}{ }_{\mathrm{cri}}\right)$ in the range of $0.001 \mathrm{M}-1 \mathrm{M}$. In additional information, the chloride concentration at which no pitting corrosion took place was defined as a critical chloride concentration (Cl-cri) as elucidated in previous paper (Priyotomo et al.,2014b). Furthermore, the pitting potential of pure $\mathrm{Al}$ is higher than that of 5052 alloy. Therefore, pitting resistance of pure $\mathrm{Al}$ is higher than that 5052 alloy.

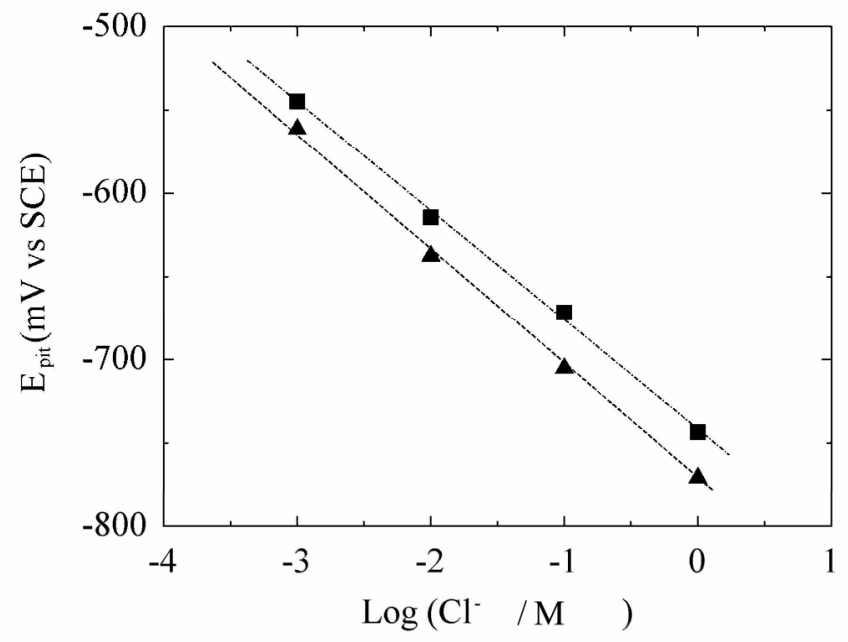

Fig.6 Chloride concentration dependence of pitting potential for A 5052 alloy dan $\boldsymbol{\square}$ pure $\mathrm{Al}$ in various neutral sodium chloride solutions at temperature of $293 \mathrm{~K}$.

In Fig.6, The relationship was found to become an identical straight line depend of chloride-ion concentration as expressed below,

$$
\begin{array}{cc}
\log \mathrm{Cl}^{-} & =-6.83 \mathrm{E}_{\text {pit }}-7.7 \quad \text { (5052 alloy) } \\
\left.\log \mathrm{Cl}^{-}=-6.71 \mathrm{E}_{\mathrm{pit}}-7.43 \quad \text { (Pure } \mathrm{Al}\right)
\end{array}
$$


The above linear equation implies that certain pitting potential becomes a relevant parameter for estimating certain chloride ion concentration. Both straight lines of two different alloys have almost same slope in which could indicate the same base metal.

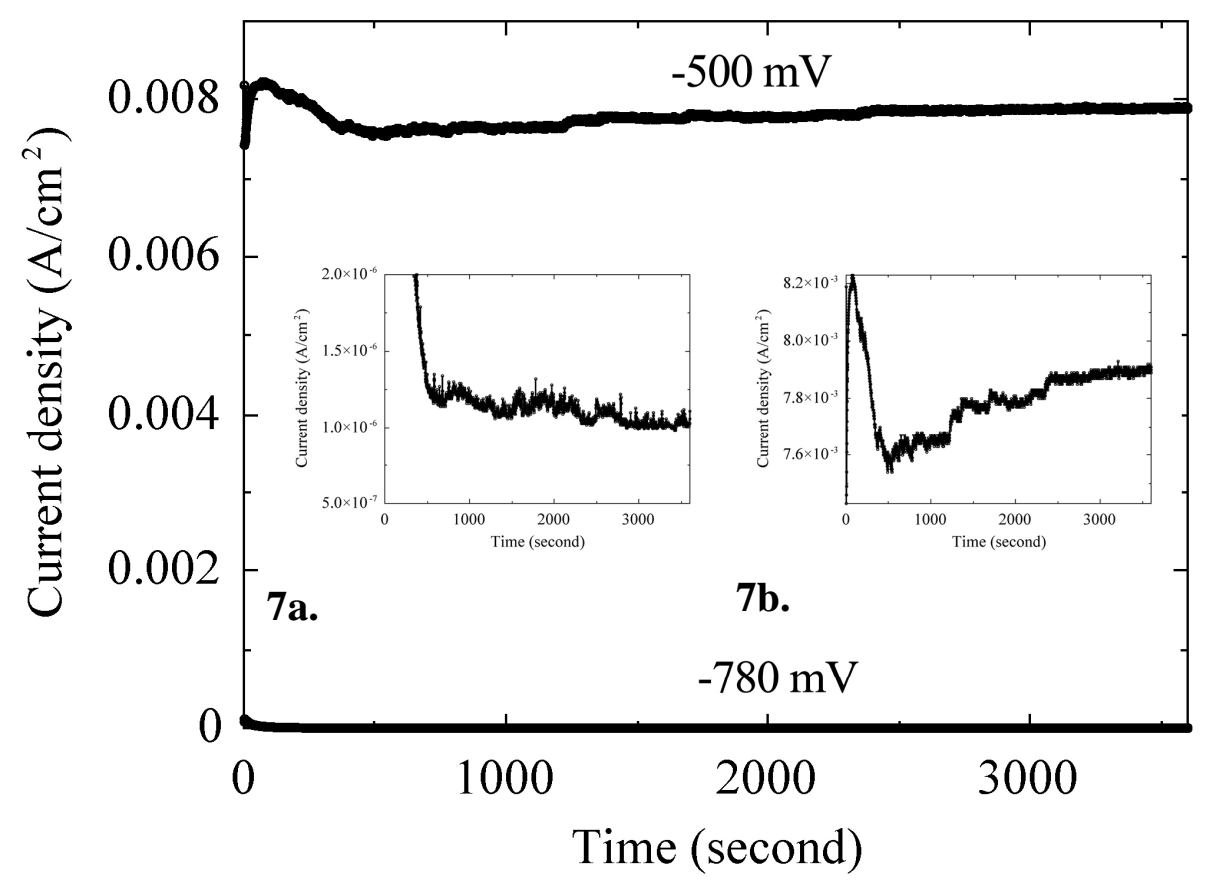

Fig. 7 Potentiostatic tests of 5052 alloy at certain constant potentials vs SCE in $0.1 \mathrm{kmol} / \mathrm{m}^{3} \mathrm{NaCl}$ solution at $293 \mathrm{~K}$

\section{Potentiostatic polarization measurement}

Fig. 7 shows that current densities of 5052 alloy recorded as a function of time for different constant potential values such as $-780 \mathrm{mV}$ and $-500 \mathrm{mV}$ vs (SCE) in $0.1 \mathrm{kmol} / \mathrm{m}^{3} \mathrm{NaCl}$ solution at $293 \mathrm{~K}$ for 3600 seconds. The current density at $-780 \mathrm{mV}$ vs SCE decreases within the time and lies down in the passivity region which started from 600 seconds of time exposure (the inserted graph of 7a ). In the inserted graph of $7 a$, the current fluctuations ( transient spikes) occurred intensively with lower magnitude. This phenomenon could be corresponded to metastable pitting. Metastable pitting can characterised by current fluctuations when an alloy is held potentistatically below $E_{\text {pit }}$ (Gupta et al.,2012). Furthermore, metastable pits initiate a potentials far below the pitting potential $\left(\mathrm{E}_{\mathrm{pit}}\right)$ and during the induction time prior to stable pit growth (Frankel et al.,1998).

On the other hand, the magnitude of current density as a function of time changed drastically, when a constant various applied potential was higher than pitting potential $\left(E_{\text {pit }}\right.$ ) in $0.1 \mathrm{kmol} \mathrm{NaCl}$ solution ( $E_{\text {pit }}:-705.2 \mathrm{mV}$ vs SCE). Furthermore, by increasing the constant applied potential above $\mathrm{E}_{\mathrm{pit}}$, the current density increase up to 3600 sec indicating the presence of stable pitting occurred on the surface as well as austenitic stainless steel such as type 304 and type 316L (Ilevbare et al.,2001). In addition, in inserted figure of $7 \mathrm{~b}$, there was no fluctuated current peak when the magnitude of current density increased with increasing the time of exposure. Therefore, it implies that there is no transition of metastable pit to stable pit on 5052 alloy compared to 25Cr duplex stainless steel (Garfias et al.,1999).

Fig. 8 shows that current densities of pure aluminium recorded as a function of time for different constant potential values such as $-735 \mathrm{mV}$ and $-660 \mathrm{mV}$ vs (SCE) in $0.1 \mathrm{M} \mathrm{NaCl}$ solution at $293 \mathrm{~K}$ for 3600 seconds. The current density at $-735 \mathrm{mV}$ vs SCE decreases within the time and turn to be steady in the passivity region which started from 600 seconds of time exposure (the inserted graph of $8 b$ ). In the inserted graph of $8 b$, the current fluctuation (transient spikes) and the magnitude of this on pure Al were lower than those of 5052 alloy. That implies that the nucleation of pits on pure $\mathrm{Al}$ were much not intense than that of $5052 \mathrm{Al}$, thus the growth of stable pits of pure Al were lower than that of 5052 alloy. As described in the previous sections, the fact could be explained above that the average size of pit for 5052 alloy is bigger than that of pure $\mathrm{Al}$. 


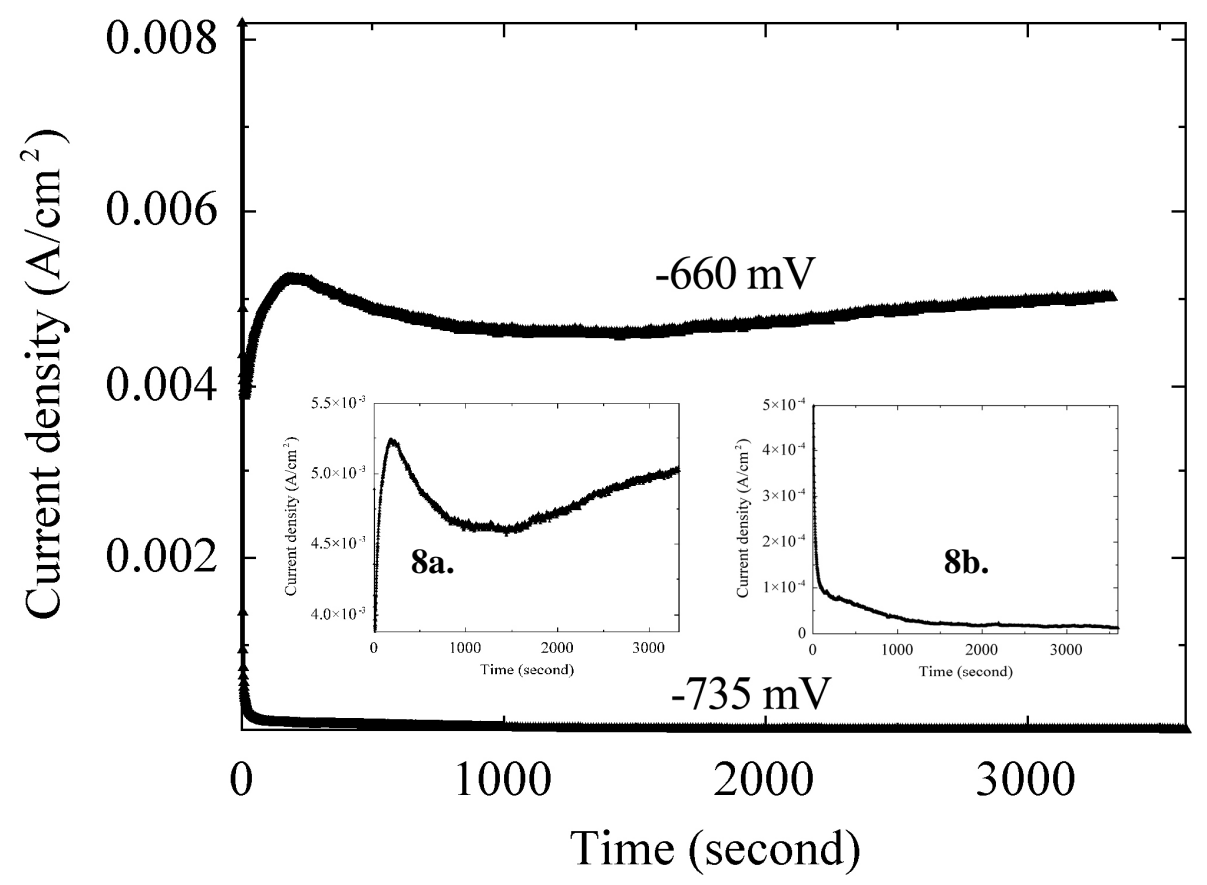

Fig. 8 Potentiostatic tests of pure $\mathrm{Al}$ at certain constant potentials vs SCE in $0.1 \mathrm{M} \mathrm{NaCl}$ solution at $293 \mathrm{~K}$

\section{E. The effect of added minor element in aluminium}

Fig 9 shows element distribution of 5052 alloy after the anodic polarization test in $0.1 \mathrm{M} \mathrm{NaCl}$ solution at ambient temperature, where this figure also shows the surface morphology using SEM. The main component of $\mathrm{Al}$ was present uniformly. The element of $\mathrm{O}$ was enriched near the edge of the pit, where indicated the presence of aluminium oxide (corrosion product). These present work suggested that the pitting initiated due to galvanic coupling between $\mathrm{Al}$ metal (anode) and iron-containing constituents (the cathode) as well as 5052 alloy in acid solution (Lockwood et al.,1985). The galvanic coupling generates the potential difference between $\mathrm{Al}$ metal and iron-containing constituents. This potential difference between the two regions led to the preferential dissolution of anode (Priyotomo et al.,2012).

Fig. 10 shows element distribution of pure $\mathrm{Al}$ after the anodic polarization test in $0.1 \mathrm{M} \mathrm{NaCl}$ solution at ambient temperature, where this figure also shows the surface morphology using SEM. The element $\mathrm{Al}$ and $\mathrm{O}$ were distributed uniformly. The role of chloride ion effect for pure $\mathrm{Al}$ was superior comparing to that for 5052 alloy. On pure $\mathrm{Al}$, when chloride ion penetrate the defected oxide film down to metal, the initiation of pitting proceeds through $\mathrm{Cl}$-assisted dissolution reaction which beneath the oxide film at the metal/oxide interface (McCafferty, 2003). In addition, for $5052 \mathrm{Al}$ alloy, the synergic effect for both chloride ion and galvanic coupling were indicated to be more severe for pitting process.
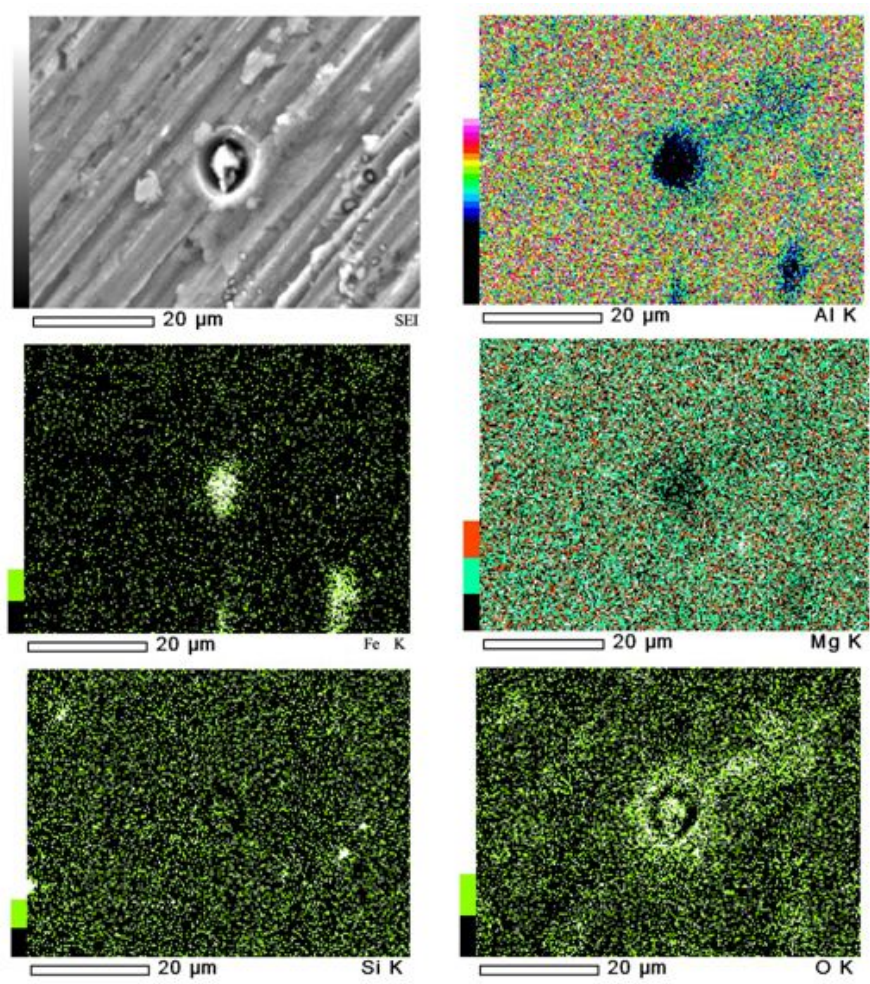

Fig. 9. Element distribution of 5052 alloy after the anodic polarization test in $0.1 \mathrm{M} \mathrm{NaCl}$ solution at ambient temperature. 

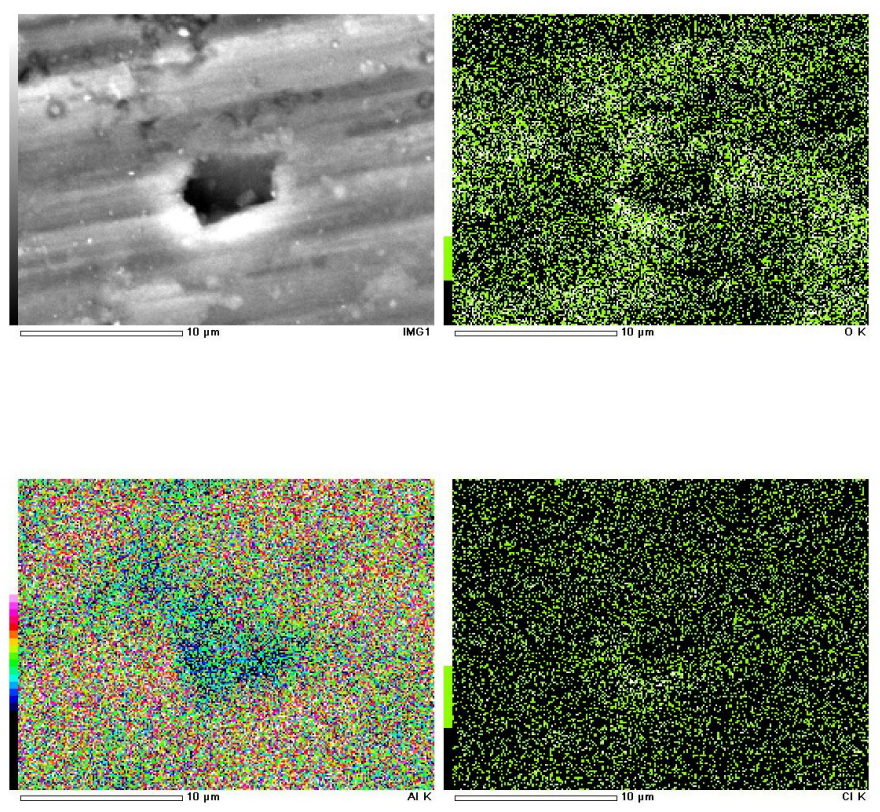

Fig. 10. Element distribution of pure $\mathrm{Al}$ after the anodic polarization test in $0.1 \mathrm{M} \mathrm{NaCl}$ solution at ambient temperature

\section{CONCLUSION}

The pitting corrosion behavior of 5052 alloy in various neutral sodium chloride solutions has been investigated and compared with that of pure Al. The following things were obtained as follows.

1. The pitting potential of 5052 alloy and pure $\mathrm{Al}$ decreased with increasing chloride concentration.

2. The pitting potential of pure $\mathrm{Al}$ is higher than that of 5052 alloy where pitting resistance of pure $\mathrm{Al}$ is better than that 5052 alloy.

3. The synergic role of chloride ion and a localized galvanic corrosion between aluminium metal and iron-containing constituent contribute the process of pitting for 5052 alloy.

4. The process of pitting for pure $\mathrm{Al}$ was caused dominantly by the role of chloride ion in penetrating the defected aluminium oxide layer.

\section{REFERENCES}

1. Elwin, L.R. (1990), Introduction to Aluminium and Aluminium Alloys. In : Properties and selection nonferrous alloys and special- purpose materials, Theodore, B.Z and Scoot D.H (Eds.), ASM International, USA : 17. ISBN : 0-87170-378-5(v.2).

2. Frankel, G.S. 1998. Pitting Corrosion of Metals A Review of the Critical Factors. JOURNAL OF THE ELECTROCHEMICAL SOCIETY, 145(6): 2186-2198.

3. Garfias-Mesias, L.F., Skykes,J.M. (1999). Metastable pitting in $25 \mathrm{Cr}$ duplex stainless steel, CORROSION SCIENCE ,30: 848-876

4. Guozhe, M., Liyan, W., Tao, Z., Yawei, S., Fuhui, W., Chaofang, D. and Xiaogang, L.(2009). Effect of microcrystallization on pitting corrosion of pure aluminium. CORROSION SCIENCE, 51 : 21512157

5. Gupta, R.K., Sukiman, N.L., Cavanaugh, M.K., Hinton, B.R.W., Hutchinson, C.R., Birbilis,N. (2012). Metastable pitting characteristics of aluminium alloys measured using current transients during potentiostatic polarisation. ELECTROCHIMICA ACTA, $66: 245-254$

6. Ilevbare, G.O. and Burstein,G.T.(2001). The role of alloyed molybdenum in the inhibition of pitting corrosion in stainless steels. CORROSION SCIENCE, 43: 485-513.

7. Kciuk, M., A. Kurc, and J. Szewczenko. (2010), Structure and corrosion resistance of aluminium AlMg2.5; AlMg5Mn and AlZn5Mg1 alloys, JOURNAL OF ACHIEVEMENT IN MATERIALS AND MANUFACTURING ENGINEERING, 41 (1-2) : 74-81.

8. Lockwood, F., S.Lee, J.Faunce and J.A.S. Green (1985). Communication of Pitting Corrosion of 5052 Aluminum Alloy. APPLICATIONS OF SURFACE SCIENCE, 20: 339-349.

9. McCafferty, E. 2003. Sequence of steps in the pitting of aluminum by chloride ions, CORROSION SCIENCE $45: 1421-1438$

10. Priyotomo, G., K. Okitsu, A. Iwase, Y. Kaneno, R. Nishimura and T.akasugi (2011), The corrosion behavior of intermetallic compounds $\mathrm{Ni}_{3}(\mathrm{Si}, \mathrm{Ti})$ and $\mathrm{Ni}_{3}(\mathrm{Si}, \mathrm{Ti})+2 \mathrm{Mo}$ in acidic solutions, APPLIED SURFACE SCIENCE, 257: 8268-8274

11. Priyotomo,G., S. Wagle, K. Okitsu, A. Iwase, Y. Kaneno, R. Nishimura, T. Takasugi (2012), The corrosion behavior of $\mathrm{Ni}_{3}(\mathrm{Si}, \mathrm{Ti})$ intermetallic compounds with $\mathrm{Al}, \mathrm{Cr}$, and $\mathrm{Mo}$ in various acidic solutions, CORROSION SCIENCE, $60: 10-17$

12. Priyotomo, G. (2013). Pitting Corrosion of $\mathrm{Ni}_{3}(\mathrm{Si}, \mathrm{Ti})$ Intermetallic Compound at Various Chloride Concentrations. INTERNATIONAL JOURNAL OF SCIENCE AND ENGINEERING,.5 (2) : 25-28.

13. Priyotomo, G., Sebleku, P. and Kaneno, Y. (2014). Pitting Corrosion of $\mathrm{Ni}_{3}(\mathrm{SI}, \mathrm{Ti})+4 \mathrm{Al}$ Intermetallic Compound at Various Chloride Concentrations. INTERNATIONAL JOURNAL OF SCIENCE AND ENGINEERING, 6(2)

14. Priyotomo, G., Sebleku, P. and Kaneno, Y. (2014). Pitting Corrosion of $\mathrm{Ni} 3(\mathrm{Si}, \mathrm{Ti})+2 \mathrm{Cr}$ Intermetallic Compound at Various Chloride Concentrations. INTERNATIONAL JOURNAL OF SCIENCE AND ENGINEERING. Vol. 7(1):10-15

15. Shao, M., Y. Fu, R. Hu and C. Lin (2002). A Study on Pitting Corrosion of Aluminum Alloy 2024-T3 by Scanning Microreference Electrode Technique, MATERIALS SCIENCE AND ENGINEERING A344:323-327.

16. Wagle, S., Priyotomo, G., Kaneno, Y., Iwase, A., Takasugi, T. and Nishimura, R.(2011). Pitting Corrosion of Intermetallic Compound $\mathrm{Ni3}(\mathrm{Si}, \mathrm{Ti})$ with 2 at\% Mo in Sodium Chloride Solutions. CORROSION SCIENCES, 55: 140-144. 